\title{
PERAN BEBAN KERJA DAN KEPUASAN KERJA TERHADAP KINERJA KARYAWAN BAGIAN JARINGAN PT. PLN (PERSERO) UP3 BOJONEGORO
}

\author{
${ }^{*}$ Nia Tufaila ${ }^{1}$. Yuniawan Heru Santoso ${ }^{2}$ \\ ${ }^{\mathbf{1}}$ Program Studi Manajemen, Fakultas Ekonomi dan Bisnis, Universitas Muhammadiyah, Surabaya \\ ${ }^{2}$ Universitas Airlangga Surabaya \\ *niiathufa@gmail.com
}

\begin{tabular}{l}
\hline Informasi Artikel \\
\hline Draft awal: Januari 2021 \\
Revisi : Februari 2021 \\
Diterima : Maret 2021 \\
Available online: Maret 2021 \\
\hline
\end{tabular}

Keywords: service quality, price, trust, intention to purchase

Tipe Artikel : Research paper

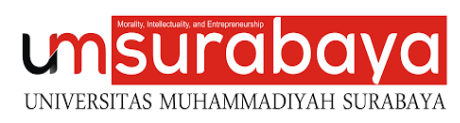

Diterbitkan oleh Universitas Muhammadiyah Surabaya

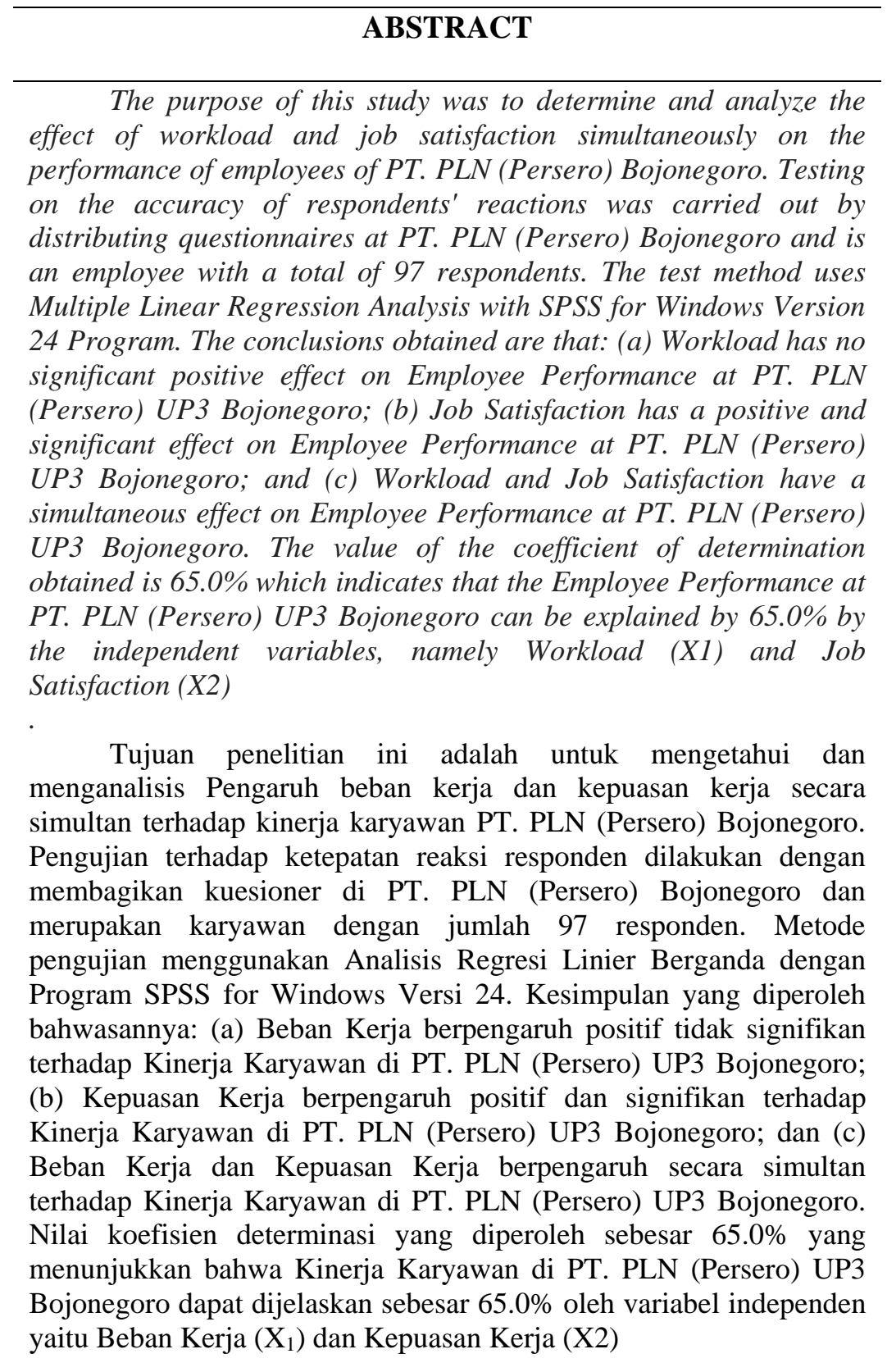

\section{PENDAHULUAN}

Perkembangan era revolusi 4.0 semakin pesat, dimana perkembangan sains dan teknologi menjadi hal mendasar dalam penentuan kualitas suatu bangsa. Sehingga dibutuhkan pendidikan yang dapat membentuk generasi kreatif, inovatif serta kompetitif. Hal ini sejalan dengan pernyataan Klaus Schwab "The fourth industrial revolution seems to be creating fewer jobs in than previous revolutions". Dengan kemajuan Artificial Inteligent, maka pekerjaan akan bergeser dari 
teknikal mekanikal manual dan pekerjaan rutin berulang ke pekerjaan inovatif. Dan nantinya kesuksesan ditentukan oleh kemampuan kolaborasi "human + robot". Adanya penggalan berita kemudian membayangkan bagaimana perilaku manusia yang akan terjadi dan terbentuk di tahuntahun setelah 2020. Akan banyak perubahan dalam perilaku organisasi karena perubahan teknologi revolusi industri generasi 4.0 ini. Perubahan dimaksud bukan berhubungan dengan teknologi sebagai piranti tapi juga terjadi perubahan pada manusia sebagai subjek dan sekaligus sebagai objek teknologi (Wahjono et al, 2020).

Era industri 4.0 membuktikan bahwa peningkatan teknologi di era digital semakin meningkat, yang ditandai dengan digitalisasi dan komputerisasi yang tidakk hanya berdampak pada bisnis, tata kelola dan masyarakat, namun juga dalam dunia pendidikan. Sehingga memunculkan persaingan yang kompetitif, sehingga dibutuhkan peran perusahaan untuk mencetak sumber daya manusia yang maksimal dan mempunya kinerja yang baik. Sehingga kelangsungan hidup perusahaan mampu dipertahankan agar dapat menghadapi pesaing yang terus bermunculan. Dibutuhkan peningkatan sumber daya manusia yang ada pada suatu perusahaan dengan strategi dan usaha yang baik, mengingat pentingnya tuntutan untuk meningkatkan kinerja sumber daya manusia.

Adanya perubahan revolusi yang serba otomatis banyak perusahaan yang ingin menjadi unggul dan memiliki karyawan yang kompeten. Salah satunya perusahaan PLN (Persero) karyawannya dituntut agar memberikan kinerja pelayanan terbaik untuk masyarakat pengguna listrik. PT. PLN (Persero) sebuah perusahaan BUMN yang mengurusi semua bidang kelistrikan yang ada di indonesia dan memiliki keunggulan untuk bersaing terutama dalam menghadapi pasar global, bisa juga dikatakan sebagai kebutuhan pokok karena dalam melakukan kegiatan seharihari selalu membutuhkan aliran listrik untuk melakukan segala aktivitas.

Adapun otomasi perusahaan yang dilakukan dalam menyambut era teknologi 4.0 dengan melakukan perbaikan dibidang pelayanan. Pada awalnya, PT PLN mulai mengembangkan fitur pelayanan dengan menyediakan jasa call center untuk melayani pelanggan. Seiring perkembangan teknologi ini formasi PT PLN kemudian menggunakan situs online dalam pelayanan berbasis internet, PLN kembali meluncurkan beberapa aplikasi baru dimana aplikasi tersebut dapat digunakan melalui smartphone/tablet berbasis android. Pada awalnya PT PLN mengeluarkan aplikasi yang dapat digunakan pada smartphone diantaranya yaitu untuk aplikasi pengecekan tagihan, aplikasi Pelayanan Pelanggan Terpusat (AP2T), PLN Mobile Learning, Tagihan PLN dan Reminder, PLN mobEl, Info PLN, dan PLNToken Rekening. PT PLN baru-baru ini PT PLN meluncurkan aplikasi PLN Mobile sebagai pengembangan dari aplikasi sebelumnya. Aplikasi PLN Mobile diluncurkan pada tanggal 31 Oktober 2016 (LayananPLN, 2016).

PT. PLN (Persero) memiliki kantor cabang di berbagai wilayah di indonesia salah satunya adalah PT. PLN (Persero) UP3 Bojonegoro yang berada di tengah kota Bojonegoro. Kantor ini melayani kebutuhan masyarakat, layanan yang di berikan seperti pengajuan pemasangan listrik, pengajuan naik tegangan, cek tagihan listrik, pembayaran listrik dan pengaduan gangguan terjadinya pemdaman listrik, masyarakat bisa komplain secara langsung ke kantor jika ada keluhan.

Sumber Daya Manusia (SDM) merupakan modal yang sangat berharga bagi sebuah perusahaan karena seluruh aktivitas / kegiatan operasional perusahaan dijalankan oleh manusia. Sekalipun perusahaan memiliki banyak mesin dalam menunjang kegiatan operasionalnya namun peran sumber daya manusia tidak dapat dipandang remeh karena untuk menjalankan seluruh mesin yang ada diperusahaan sangat membutuhkan sumber daya manusia. Tingginya efektifitas dalam menangani sumber daya manusia dalam hal ini adalah karyawan, maka berpengaruh terhadap kualitas dari karyawan itu sendiri. Semakin banyak hal yang diperhatikan oleh perusahaan terhadap karyawan, maka semakin baik pula kinerja dari karyawan tersebut. Menurunnya kinerja karyawan yang terjadi pada suatu perusahaan akan menimbulkan dampak negatif bagi perusahaan. Oleh karena itu kualitas sumber daya manusia harus senantiasa di kembangkan agar tidak ada terjadinya penurunan kinerja dan target yang telah ditetapkan perusahaan untuk mencapai perkembangan perusahaan semakin efektif dan efesien.

Setiap perusahaan perlu meningkatkan kinerja karyawannya, karena kinerja karyawan berperan penting dalam setiap perencanaan, pelaksanaan, dan pengendalian dalam berbagai strategi di perusahaan untuk mencapai visi, misi dan tujuan yang telah ditetapkan perusahaan. Sutrisno (2015, p. 170) kinerja adalah hasil kerja yang dapat dicapai oleh seseorang atau sekelompok orang dalam suatu organsiasi sesuai dengan wewenang dan tanggung jawab masingmasing dalam upaya mencapai tujuan organisasi 
bersangkutan secara legal,tidak melanggar hukum dan sesuai dengan modal dan etika. Rivai (2014, p. 97) kinerja karyawan tidak hanya sekedar informasi untuk dapat dilakukannya promosi atau penetapan gaji bagi perusahaan akan tetapi bagaimana perusahaan dapat memotivasi karyawan dan mengembangkan satu rencana untuk memperbaiki kemerosotan kerja dapat dihindari. Sedangkan Wibowo (2016, p. 7) menjelaskan kinerja adalah bagaimana melakukan pekerjaan dengan mencapai hasil akhir yang diharapkan. Untuk mencapai target yang ditetapkan perusahaan, karyawan harus mengutamakan kepentingan dan kepuasan dengan memberikan layanan terbaik, disiplin, bekerja dengan baik dan inovasi sehingga akan menghasilkan kinerja yang baik (Pio, 2015)

Tabel 1. Jumlah Karyawan Bagian Jaringan Tahun 2019-2020

\begin{tabular}{ccc}
\hline No & Bagian & Jumlah karyawan \\
\hline 1 & Operasi & 10 \\
2 & Pemeliharaan & 15 \\
3 & PDKB & 30 \\
\hline
\end{tabular}

Sumber: Regional Manajer UP3 Bojonegoro Bagian Jaringan

Berdasarkan tabel diatas menunjukkan bahwa jumlah karyawan dbagian jaringan di PT.PLN (Persero) UP3 Bojonegoro tahun 20192020 sebanyak 55 karyawan dengan rata-rata bekerja selama 8 jam dan penambahan di luar jam kerja adalah 4-5 jam.

Tabel 2. Jumlah Karyawan Cabang (Unit Layanan Pelanggan) ULP Bojonegoro Tahun 2019-2020

\begin{tabular}{ccc}
\hline No. & Kabupaten & $\begin{array}{c}\text { Jumlah } \\
\text { karyawan }\end{array}$ \\
\hline 1 & Bojonegoro & 12 \\
2 & Tuban & 15 \\
3 & Lamongan & 11 \\
4 & Babat & 9 \\
5 & Padangan & 9 \\
6 & Jatirogo & 8 \\
7 & Brondong & 8 \\
8 & Sumberrejo & 9 \\
\hline
\end{tabular}

Sumber: Regional Manajer UP3 Bojonegoro Bagian Jaringan

Unit Pelaksana Pelayanan Pelanggan (UP3) Bojonegoro juga dibantu oleh Unit Layanan Pelanggan (ULP) yang berada di tiap Kabupaten untuk dapat menyelesaikan permasalahan penurunan ganggunan dengan jumlah 81 karyawan. Tidak jauh berbeda dengan target dan tuntutan pekerjaan yang dalamkesehariannya ratarata bekerja selama 8 jam kerja dan penambahan diluar jam kerja meskipun tidak sebanyak permasalahan yang ada dipusat.

Tabel 3. Data Program Penurunan Gangguan Penyulang Karyawan Bagian Jaringan PT. PLN (Persero) UP3 Bojonegoro Tahun 2017-2019

\begin{tabular}{ccc}
\hline Tahun & Target & Realisasi \\
\hline 2017 & 360 & 298 \\
2018 & 395 & 368 \\
2019 & 395 & 340 \\
\hline
\end{tabular}

Sumber : Regional Manajer UP3 Bojonegoro Bagian Jaringan

Berdasarkan tabel diatas menunjukkan bahwa tingkat target kerja pertahun tidak mencapai realisasi, perlu adanya tambahan sumber daya manusia pada karyawan bagian jaringan. Jumlah karyawan bagian jaringan UP3 Bojonegoro sebanyak 55 dan karyawan bagian jaringan ULP Bojonegoro sebanyak 81 karyawan yang masingmasing Unit tersebut dibagi menjadi tiga bagian dengan rata rata jam kerja yang lebih dari 8 jam perhari maka target kerja tidak maksimal, beban kerja yang terlalu berlebihan akan menyebabkan dampak buruk bagi karyawan.

Beban kerja merupakan suatu kondisi dari pekerjaan dengan uraian tugasnya yang harus diselesaikan pada batas waktu tertentu, ,beban kerja dapat dilihat dari beban kerja fisik maupun mental, apabila beban kerja yang ditanggung seseorang terlalu berat atau kemampuan fisik yang lemah tentu akan mengakibatkan suatu hambatan dalam bekerja sehingga karyawan tersebut akan merasa sakit karena suatu pekerjaan (Munandar, 2012, p. 383).

Beban pekerjaan yang terlalu banyak dan dapat menyebabkan ketegangan dalam diri seseorang sehingga menimbulkan stres. hal ini dapat disebabkan oleh tingkat keahlian yang dituntut terlalu tinggi, tingkat kecepatan yang terlalu tinggi, volume pekerjaan yang terlalu banyak. Sunyoto (2012, p. 64). Dengan adanya beban kerja yang tidak sesuai oleh seseorang individu akan menimbulkan dampak negatif dari seseorang individu itu sendiri terhadap kinerjanya dan juga akan berdampak dengan perusahaan. Menurut Gibson et al, (2012, p. 56) menjelaskan bahwa individu menjadi faktor penentu untuk menyesuaikan diri dalam pekerjaan yang di pengaruhi ketidaksamaan individu atau faktor kelainan yang berasal dari pengaruh luar (lingkungan, situasi) terhadap seseorang.

Selain beban kerja, kepuasan kerja juga turut berpengaruh terhadap kinerja. Kepuasan kerja 
menjadi salah satu masalah yang cukup menarik dan penting, karena terbukti besar manfaatnya bagi kepentingan individu, perusahaan dan masyarakat. Kepuasan kerja pun akan berdampak kepada tingkat loyalitas karywan terhadap perusahaan sehingga karyawan tidak akan mudah untuk pindah atau mengundurkan diri dari perusahaan tempat mereka bekerja. Dengan adanya kepuasan kerja yang tinggi maka akan berdampak pada kesenangan karyawan dalam melakukan setiap pekerjaannya. Menurut Robbin \& Timothy (2015, p. 148) kepuasaan kerja adalah sikap umum terhadap pekerjaan seseorang, yang menunujukkan perbedaan antara jumlah penghargaan yang diterima pekerja dan jumlah yang mereka yakini seharusnya mereka terima.

Kepuasan kerja bukanlah seberapa keras atau seberapa baik seseorang bekerja, melainkan seberapa jauh seseorang menyukai pekerjaan tertentu. Kepuasan kerja berhubungan dengan perasaan atau sikap seseorang mengenai pekerjaan itu sendiri, gaji, kesempatan promosi atau pendidikan, pengawasan, rekan kerja, beban kerja dan lain sebagainya. Sedangkan Menurut Hasibuan (Hasibuan, 2016, p. 40) menjelaskan kepuasan kerja pada dasarnya merupakan merupakan sikap emosional yang menyenangkan dan mencintai pekerjaannya. Sikap ini dicerminkan oleh moral kerja, kedisiplinan, dan prestasi kerja. Kepuasan kerja karyawan harus diciptakan sebaik-baiknya supaya moral kerja, dedikasi, kecintaan, dan kedisiplinan karyawan meningkat. Karyawan sendiri menurut Hasibuan adalah setiap orang yang bekerja dengan menjual tenaganya (fisik dan pikiran) kepada suatu perusahaan dan memperoleh imbalan atas jasa yang diberikan kepada perusahaan.

\section{METODE}

Penelitian ini dilaksanakan di PT. PLN (Persero) UP3 Bojonegoro berlokasi di Jl. Teuku Umar No.3, Kadipaten, Kec. Bojonegoro, Kabupaten Bojonegoro, Jawa Timur 62111.

Penelitian ini menggunakan pendekatan penelitian kuantitatif. Penelitian kuantitatif adalah penelitian yang menggunakan pendekatan yang bersifat obyektif, mencakup pengumpulan dan analisis data kuantitatif serta menggunakan metode pengujian statistik (Fatihudin, 2015). Data yang digunakan adalah data primer yaitu data dari jawaban responden yang selanjutnya diolah dengan menggunakan analisis regresi liner berganda, analisis reliabilitas, dan validitas, uji asumsi klasik, analisis koefisien determinasi berganda, koefisien korelasi berganda, uji $\mathrm{t}$ dan uji $\mathrm{F}$ untuk mengetahui pengaruh variabel Beban Kerja $\left(\mathrm{X}_{1}\right)$ dan Kepuasan Kerja $\left(\mathrm{X}_{2}\right)$ terhadap Kinerja Karyawan Bagian Jaringan PT. PLN (Persero) UP3 Bojonegoro (Y).

\section{Teknik Pengumpulan Data}

Terdapat dua cara untuk mengumpulkan data yang akan diperlukan untuk melakukan analisis dalam penelitian ini, yaitu sebagai berikut:

1. Pengumpulan Data Primer

Pengertian data primer menurut (Sugiyono, 2015) adalah sumber data yang langsung memberikan data kepada pengumpul data. Data ini diperoleh melalui studi lapangan dengan menyebarkan kuesioner yang akan diisi oleh responden pada Karyawan Bagian Jaringan PT. PLN (Persero) UP3 Bojonegoro.

2. Pengumpulan Data Skunder

Data sekunder diperoleh melalui peneliti dari dokumen perusahaan seperti struktur organisasi dan data sejarah Bagian Jaringan PT. PLN (Persero) UP3 Bojonegoro.

Populasi pada penelitian ini adalah seluruh karyawan bagian jaringan PT. PLN (Persero) UP3 Bojonegoro dan ULP Bojonegoro sejumlah 136 orang.

Tabel 4. Jumlah Karyawan Bagian Jaringan Tahun 2019-2020

\begin{tabular}{ccc}
\hline No & Bagian & Jumlah karyawan \\
\hline 1 & Operasi & 10 \\
2 & Pemeliharaan & 15 \\
3 & PDKB & 30 \\
\hline $\begin{array}{l}\text { Sumber : } \\
\text { Jaringan }\end{array}$
\end{tabular}

Tabel 5. Jumlah Karyawan Cabang (Unit Layanan Pelanggan) ULP Bojonegoro Tahun 2019-2020

\begin{tabular}{ccc}
\hline No. & Kabupaten & Jumlah karyawan \\
\hline 1 & Bojonegoro & 12 \\
2 & Tuban & 15 \\
3 & Lamongan & 11 \\
4 & Babat & 9 \\
5 & Padangan & 9 \\
6 & Jatirogo & 8 \\
7 & Brondong & 8 \\
8 & Sumberrejo & 9 \\
\hline
\end{tabular}

Sumber: Regional Manajer UP3 Bojonegoro Bagian Jaringan

\section{Sampel}

Menurut Sugiyono (2015, p. 62), dalam menentukan besarnya sampel yaitu menggunakan tabel Krejcie. Krejcie dalam melakukan 
perhitungan ukuran sampel didasarkan atas kesalahan 5\%. Jadi sampel yang diperoleh itu mempunyai kepercayaan $95 \%$ terhadap populasi. Maka pengambilan jumlah sampel mengacu berdasarkan pada tabel Krejcie, yaitu dengan jumlah populasi antara 130 sampai 139 maka sampel yang digunakan sebanyak 97. Sehingga dalam penelitian ini dengan jumlah sample sebanyak 97 karyawan, maka sampel yang akan diambil sebanyak 97 karyawan. Pengambilan sampel berdasarkan tabel Krejcie berikut ini:

Pengambilan sampel dilakukan dengan metode purposive sampling. Dalam teknik pengambilan sampel ini peneliti menggunakan teknik sampling purposive. Sugiyono (2015, p. 84) menjelaskan bahwa: "Sampling Purposive adalah teknik penentuan sampel dengan pertimbangan tertentu". Adapun kriteria yang digunakan untuk menentukan sampel adalah 97 responden dan merupakan karyawan bagian jaringan PT. PLN (Persero) UP3 Bojonegoro dan ULP Bojonegoro.

Pengolahan data merupakan proses penerimaan data sebagai masukan (input) kemudian diproses oleh suatu program tertentu dan mengeluarkan hasil proses data dengan komputer yang dikenal dengan EDP (Electric Data Processing). Teknik analisa yang digunakan pada penelian ini adalah regresi linear berganda. Pengolahan data yang dilakukan dalam penelitian ini menggunakan program SPSS (Statistical Product and Service Solution) versi 24, sehingga pemrosesan data berjalan secara otomatis dan kemudian diinterpretasikan hasilnya. Teknik analisis yang digunakan dalam penelitian ini adalah regresi linier berganda yaitu dengan melihat pengaruh antara variabel Beban Kerja $\left(X_{1}\right)$ dan Kepuasan Kerja $\left(\mathrm{X}_{2}\right)$ terhadap Kinerja Karyawan (Y).

\section{HASIL DAN PEMBAHASAN}

\section{Hasil}

\section{Gambaran Penyebaran Kuesioner}

Penelitian ini menggunakan kuesioner yang disebarkan langsung kepada responden yang merupakan karyawan bagian jaringan PT. PLN (Persero) UP3 Bojonegoro sejumlah 97 orang serta dalam pengumpulan datanya menggunakan kuesioner yang cara pengisiannya sendiri dengan menggunakan bantuan aplikasi Google Form, dikarenakan PT. PLN (Persero) UP3 Bojonegoro sudah melek teknologi karyawannya.

\section{Gambaran Umum Kuesioner}

Berdasarkan Tabel 6 dapat dilihat bahwa deskripsi data yang akan disajikan dari hasil penelitian ini adalah untuk memberikan gambaran secara umum mengenai kuesioner yang akan disebar untuk responden. Jumlah pertanyaan pada kuesioner yang dikirimkan sebanyak 97 orang pertanyaan yang ikhtisarnya sebagai berikut:

Tabel 6 Gambaran Umum Kuesioner

\begin{tabular}{|c|c|c|c|c|}
\hline No. & Variabel & Variabel & $\begin{array}{l}\text { Skala } \\
\text { Likert }\end{array}$ & Jumlah \\
\hline 1. & $\mathrm{X} 1$ & Beban Kerja & $1-5$ & 8 Pertanyaan \\
\hline 2. & $\mathrm{X} 2$ & $\begin{array}{l}\text { Kepuasan } \\
\text { Kerja }\end{array}$ & $1-5$ & 10 Pertanyaan \\
\hline 3. & $\mathrm{Y}$ & Kinerja & $1-5$ & 10 Pertanyaan \\
\hline \multicolumn{4}{|c|}{ Jumlah Pertanyaan } & 28 Pertanyaan \\
\hline
\end{tabular}

Sumber data: Hasil Olahan Kuesioner, 2021

\section{Karakteristik Responden}

Responden dalam penelitian ini merupakan karyawan bagian jaringan PT. PLN (Persero) UP3 Bojonegoro sebanyak 97 orang untuk dapat diketahui karakteristiknya berdasarkan jenis kelamin, divisi, Usia dan pendidikan.

Perbandingan jumlah responden berdasarkan jenis kelamin menunjukkan 83 laki $(85,6 \%)$, dan $14(14,4 \%)$ perempuan sehigga laki-laki yang lebih dominan dalam penelitian ini sebagai responden. Dikarenakan pekerjaan yang ada di PT. PLN (Persero) UP3 Bojonegoro bergerak dibidang kelistrikan dan berat sehingga memakan tenaga lebih banyak dan lebih dibutuhkan karyawan berjenis kelamin laki-laki dan masih dalam kategori produktif.

Diketahui bahwa responden dalam penelitian ini di dominasi oleh responden dengan divisi Operasi sebanyak 46 orang $(47,4 \%)$, sedangkan responden paling sedikit adalah lainnya sebanyak $3(3,1 \%)$. Jumlah Lainnya yang paling sedikit dikarenakan operasional ini adalah bagian yang tidak ingin diketahui bagiannya yang ada di dalam kantor, utamanya bagian pimpinan. Sedangkan untuk bagian Operasi/Operasional yang melakukan perbaikan langsung ke konsumen berupa perbaikan jaringan seperti penambahan watt jaringan, perbaikan konsleting dan lainnya.

berdasarkan usia responden paling banyak berada di kategori usia $\leq 25$ Tahun yaitu sebanyak 48 orang $(49,5 \%)$. Sedangkan pada kategori usia > 45 Tahun terdapat responden sebanyak 1 orang (1\%). Dikarenakan pekerjaan yang ada di PT. PLN (Persero) UP3 Bojonegoro bergerak dibidang kelistrikan yang mempunyai target besar untuk pelayanan masyarakat dan memiliki risiko yang besar pula, sehingga lebih membutuhkan tenaga 
kerja yang lebih besar sehingga usia karyawan masih dalam kategori produktif.

Keseluruhan responden dalam penelitian ini didominasi oleh responden yang memiliki pendidikan akhir SMA/SMK yaitu sebanyak 55 responden $(56,7 \%)$. Tingkat pendidikan rata-rata berada ditingkat SMA/SMK, artinya PT. PLN (Persero) UP3 Bojonegoro yang bergerak dibidang pelayanan jaringan terbesar di Indonesia dan dalam proses kerjanya lebih membutuhkan usia produktif dan pendidikan yang tidak terlalu tinggi, meskipun demikian karyawan tetap memberikan kontribusi terbaiknya serta memiliki tekat bekerja yang sangat baik sehingga membuat Beban Kerja menjadi lebih optimal dan kinerja yang kondusif.

\section{Uji Validitas Instrumen}

Uji validitas digunakan untuk mengukur valid tidaknya suatu kuisioner. Dalam hal ini digunakan indikator pernyataan yang diharapkan dapat secara tepat mengungkapkan variabel yang diukur. Suatu instrumen dapat dinyatakan valid atau layak digunakan dalam pengujian hipotesis apabila Corrected Item-Total Correlation > 0,30 (Sugiyono, 2015, p. 124).

Tabel 7. Validitas Variabel Beban Kerja

\begin{tabular}{lrrr} 
Item-Total Statistics & & \\
\hline & $\begin{array}{c}\text { Corrected } \\
\text { Item-Total } \\
\text { Correlation }\end{array}$ & $\begin{array}{c}\text { Cronbach's } \\
\text { Alpha if Item } \\
\text { Deleted }\end{array}$ & Valid \\
\hline X1_1 & .399 & .734 & Valid \\
X1_2 & .394 & .734 & Valid \\
X1_3 & .518 & .714 & Valid \\
X1_4 & .516 & .711 & Valid \\
X1_5 & .600 & .695 & Valid \\
X1_6 & .421 & .733 & Valid \\
X1_7 & .445 & .726 & Valid \\
X1_8 & .317 & .751 & Valid \\
\hline
\end{tabular}

Sumber : Hasil Output SPSS 24

Berdasarkan Tabel 7 dapat disimpulkan bahwa indikator Variabel Beban Kerja (X1) pernyataan yang digunakan dalam penelitian ini valid atau layak digunakan dalam pengujian hipotesis. Hal tersebut dapat dilihat dari nilai masing-masing indikator pernyataan yang memiliki Corrected Item-Total Correlation > 0,30 (Sugiyono, 2015, p. 124).

Tabel 8. Validitas Variabel Kepuasan Kerja

Item-Total Statistics

\begin{tabular}{ccc}
\hline Corrected Item- & Cronbach's & \\
Total & Alpha if Item & Valid \\
Correlation & Deleted & \\
\hline
\end{tabular}

\begin{tabular}{rlrl}
\hline X2_1 & .436 & .863 & Valid \\
X2_2 & .560 & .854 & Valid \\
X2_3 & .553 & .854 & Valid \\
X2_4 & .555 & .854 & Valid \\
X2_5 & .565 & .853 & Valid \\
X2_6 & .683 & .845 & Valid \\
X2_7 & .632 & .848 & Valid \\
X2_8 & .588 & .851 & Valid \\
X2_9 & .633 & .848 & Valid \\
X2_10 & .579 & .852 & Valid \\
\hline
\end{tabular}

Sumber : Hasil Output SPSS 24

Berdasarkan Tabel 8, dapat disimpulkan bahwa seluruh indikator Variabel Kepuasan Kerja (X2) pernyataan yang digunakan dalam penelitian ini valid atau layak digunakan dalam pengujian hipotesis. Hal tersebut dapat dilihat dari nilai masing-masing indikator pernyataan yang memiliki Corrected Item-Total Correlation > 0,30 (Sugiyono, 2015, p. 124).

Tabel 9. Validitas Variabel Kinerja Karyawan Item-Total Statistics

\begin{tabular}{rrrr}
\hline & $\begin{array}{c}\text { Corrected } \\
\text { Item-Total } \\
\text { Correlation }\end{array}$ & $\begin{array}{c}\text { Cronbach's } \\
\text { Alpha if Item } \\
\text { Deleted }\end{array}$ & Valid \\
\hline Y1_1 & .628 & .897 & Valid \\
Y1_2 & .518 & .903 & Valid \\
Y1_3 & .586 & .899 & Valid \\
Y1_4 & .649 & .895 & Valid \\
Y1_5 & .630 & .897 & Valid \\
Y1_6 & .710 & .891 & Valid \\
Y1_7 & .760 & .888 & Valid \\
Y1_8 & .664 & .894 & Valid \\
Y1_9 & .685 & .893 & Valid \\
Y1_10 & .760 & .888 & Valid \\
\hline Sumber: Hasil Output SPSS 24 & &
\end{tabular}

Berdasarkan Tabel 9 dapat disimpulkan bahwa seluruh indikator Kinerja Karyawan (Y) perryataan yang digunakan dalam penelitian ini valid atau layak digunakan dalam pengujian hipotesis. Hal tersebut dapat dilihat dari nilai masing-masing indikator pernyataan yang memiliki Corrected Item-Total Correlation > 0,30 (Sugiyono, 2015, p. 124).

Uji Reliabilitas Instrumen

Reliabilitas digunakan untuk menunjukkan sejauh mana alat ukur dapat dipercaya atau dihandalkan. Uji reliabilitas dilakukan dengan melihat nilai Cronbach's Alpha dengan kriteria reliabel apabila nilai Cronbach's Alpha lebih dari 0,6 (Akdon \& Riduwan, 2013). Hasil uji reliabilitas dapat disajikan pada Tabel 10 sebagai berikut: 
Tabel 10. Uji Reliabilitas

\begin{tabular}{ccc}
\hline Variabel & $\begin{array}{c}\text { Cronbach's } \\
\text { Alpha }\end{array}$ & Keterangan \\
\hline $\begin{array}{c}\text { Beban Kerja } \\
\left(\mathrm{X}_{1}\right)\end{array}$ & 0,751 & Reliabel \\
$\begin{array}{c}\text { Kepuasan } \\
\text { Kerja (X2) } \\
\text { Kinerja }\end{array}$ & 0,865 & Reliabel \\
Karyawan (Y) & 0,904 & Reliabel \\
\hline Kumber: Hasil Output SPSS 24
\end{tabular}

Sumber : Hasil Output SPSS 24

Berdasarkan hasil uji reliabilitas maka dapat disimpulkan bahwa seluruh item yang digunakan dalam kuesioner pada masing-masing variabel yang digunakan dalam penelitian ini adalah reliabel, hal tersebut dikarenakan nilai Skor kehandalan (reliabilitas) yang dapat diterima Cronbach's Alpha lebih dari 0,7 (Malhotra, 2010, p. 319)

\section{Uji Asumsi Klasik}

Uji asumsi yang harus terpenuhi pada analisis regresi linier berganda adalah uji normalitas, uji multikolinearitas, uji heteroskedastisitas dan uji autokorelasi.

a. Uji Normalitas

Uji normalitas adalah uji untuk mengetahui normalitas dan bertujuan untuk menguji apakah variabel terikat dan variabel bebas keduanya mempunyai distribusi normal atau tidak. Sehingga apabila data tersebut memiliki distribusi normal maka uji-t dapat dilakukan, sementara apabila asumsi normalitas tidak dapat dipenuhi maka inferensi tidak dapat dilakukan dengan statistik t.

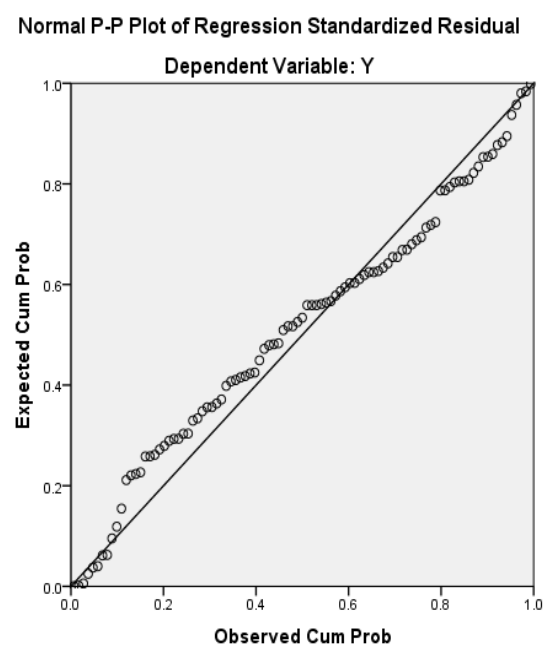

Gambar 1. Grafik P-P Plot Uji Normalitas Sumber : Hasil Output SPSS 24
Hasil uji normalitas dengan Normal P-P Plot ditunjukkan pada Gambar 1. Hasil uji normalitas dengan Normal P-P Plot menunjukkan bahwa angka probabilitas disekitar garis linier atau lurus. Artinya bahwa seluruh variabel yang mempengaruhi Kinerja Karyawan digunakan dalam penelitian memiliki random data yang berdistribusi normal, sehingga pengujian statistik selanjutnya dapat dilakukan.

b. Uji Multikolinearitas

Uji multikolinearitas bertujuan untuk mengetahui ada tidaknya hubungan linear yang sempurna diantara variabelvariabel bebas dalam regresi. Untuk mengetahui ada tidaknya gejala multikolinearitas dapat dilihat dari besarnya nilai tolerance dan VIF (Varians Inflation Faktor). Kriteria yang dipakai adalah apabila nilai tolerance $>0,1$ atau nilai VIF < 10 maka tidak terjadi multikolinearitas. Hasil uji multikolinearitas disajikan pada Tabel 11.

Tabel 11. Uji Multikolinearita

\begin{tabular}{|c|c|c|c|c|c|}
\hline \multicolumn{6}{|c|}{ Coefficients $^{a}$} \\
\hline \multirow[b]{2}{*}{ Model } & \multicolumn{2}{|c|}{$\begin{array}{c}\text { Unstandardize } \\
\text { d Coefficients } \\
\text { Std. }\end{array}$} & \multicolumn{3}{|c|}{$\begin{array}{l}\text { Collinearity } \\
\text { Statistics } \\
\text { Tolera }\end{array}$} \\
\hline & B & Error & Sig. & nce & VIF \\
\hline $\begin{array}{l}1 \text { (Const } \\
\text { ant) }\end{array}$ & .368 & .307 & .234 & & \\
\hline $\mathrm{X} 1$ & .062 & .099 & .529 & .536 & 1.866 \\
\hline $\mathrm{X} 2$ & .839 & .091 & .000 & .536 & 1.866 \\
\hline
\end{tabular}

Berdasarkan Tabel 11 dapat diketahui hasil perhitungan menunjukan bahwa nilai nilai tolerance $>0,1$ atau nilai VIF < 10. Hal ini dapat disimpulkan bahwa persamaan model regresi tidak mengandung masalah multikolinieritas yang artinya tidak ada korelasi yang signifikan diantara variabel-variabel bebas sehingga layak digunakan untuk analisis lebih lanjut.

c. Uji Heteroskedastisitas

Heteroskedastisitas muncul ketika varian dari distribusi probabilitas gangguan tidak konstan untuk seluruh pengamatan atas variabel penelitian. Metode yang digunakan untuk menguji heteroskedastisitas dalam penelitian ini memakai diagram scatterplot. 
Berdasarkan Gambar 2 dapat disimpulkan bahwa tidak ada pola yang jelas dalam pengujian terhadap variabel Kinerja Karyawan, serta titik-titik menyebar keatas dan dibawah 0 pada sumbu Y maka tidak terjadi heteroskedastisitas.

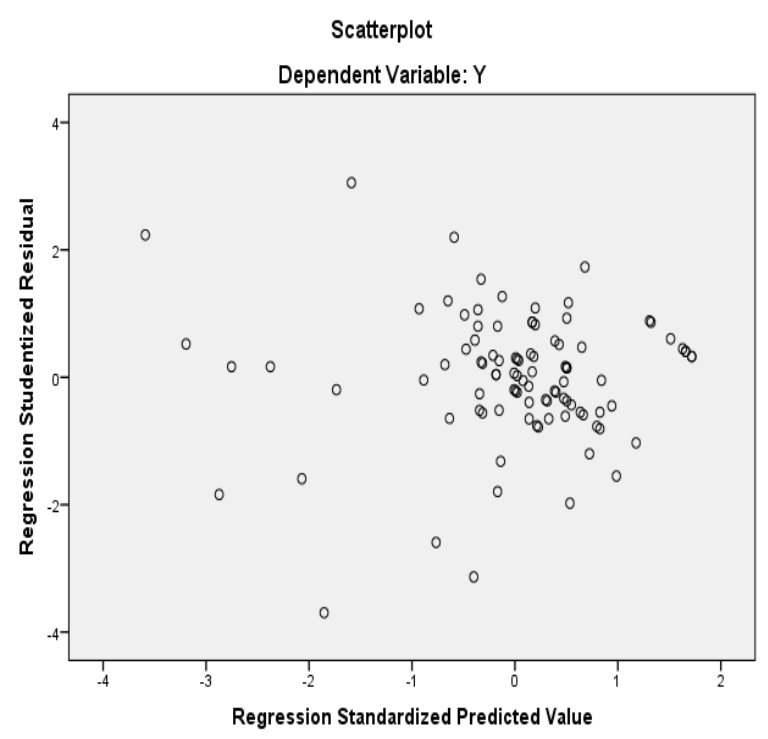

Gambar 2. Diagram Scatterplot Sumber : Hasil Output SPSS 24

\section{d. Uji Autokorelasi}

Autokorelasi pada model regresi artinya ada korelasi antar anggota sampel yang diurutkan berdasarkan waktu saling berkorelasi.Untuk mengetahui adanya autokorelasi dalam suatu model regresi dilakukan melalui pengujian terhadap nilai uji Durbin Watson (Uji DW). Suatu model dikatakan bebas autokorelasi jika dhitung (Durbin Watson) terletak antara -2 dan 2.

Tabel 12. Uji Autokorelasi

\begin{tabular}{|c|c|c|c|c|}
\hline \multicolumn{5}{|c|}{ Model Summary ${ }^{b}$} \\
\hline $\begin{array}{l}\text { M } \\
\text { od } \\
\text { el }\end{array}$ & $\mathrm{R}$ & $\begin{array}{c}\mathrm{R} \\
\text { Square }\end{array}$ & $\begin{array}{c}\text { Std. } \\
\text { Erro } \\
\mathrm{r}\end{array}$ & $\begin{array}{l}\text { Durbin- } \\
\text { Watson }\end{array}$ \\
\hline 1 & $\begin{array}{r}.806 \\
a\end{array}$ & .650 & $\begin{array}{r}.387 \\
37\end{array}$ & 2.062 \\
\hline
\end{tabular}

a. Predictors: (Constant), X2, X1

b. Dependent Variabel: Y

Sumber : Hasil Output SPSS 24

Berdasarkan Tabel 12. diperoleh hasil uji Durbin Watson, diperoleh nilai dhitung sebesar 2.062. Nilai DW menurut tabel dengan $\mathrm{n}=97$ dan $\mathrm{k}=3$ didapat angka dl (lower) $=1.62752$ dan du (upper) $=$ 1.71157. Berdasarkan teori yang disebutkan sebelumnya dimana jika nilai dhitung (Durbin Watson) terletak antara nilai DW hitung > dl $(2.062>1.62752)$. Maka dapat disimpulkan bahwa tidak ditemukannya autokorelasi dalam model regresi.

e. Uji Regresi Linier Berganda

Yakni suatu analisis untuk melihat sejauh mana pengaruh variabel Beban Kerja dan Kepuasan Kerja terhadap variabel Kinerja Karyawan di usaha PT. PLN (Persero) UP3 Bojonegoro. Analisis regresi linier berganda menggunakan rumus persamaan seperti yang dikutip dalam (Ghozali, 2013, p. 139), yakni:

$$
\mathrm{Y}=\mathrm{a}+\mathrm{b}_{1} \mathrm{X}_{1}+\mathrm{b}_{2} \mathrm{X}_{2}+\ldots \mathrm{b}_{\mathrm{n}} \mathrm{X}_{\mathrm{n}}+\mathrm{e}
$$

Tabel 13. Hasil Uji Regresi Linier Berganda

Coefficients $^{\text {a }}$

\begin{tabular}{|c|c|c|c|c|}
\hline \multirow[t]{2}{*}{ Model } & \multicolumn{2}{|c|}{$\begin{array}{l}\text { Unstandardized } \\
\text { Coefficients }\end{array}$} & \multirow[t]{2}{*}{$\mathrm{t}$} & \multirow[t]{2}{*}{ Sig. } \\
\hline & $\mathrm{B}$ & Std. Error & & \\
\hline $\begin{array}{l}\text { (Consta } \\
\text { nt) }\end{array}$ & .368 & .307 & 1.198 & .234 \\
\hline $\mathrm{X} 1$ & .062 & .099 & .632 & .529 \\
\hline $\mathrm{X} 2$ & .839 & . 091 & 9.235 & .000 \\
\hline
\end{tabular}

a. Dependent Variable: Y

Sumber : Hasil Output SPSS 24

Berdasarkan Tabel 13. dapat dituliskan model regresi linier berganda mengenai pengaruh variabel Beban Kerja $\left(\mathrm{X}_{1}\right)$ dan Kepuasan Kerja (X2) terhadap variabel Kinerja Karyawan di usaha PT. PLN (Persero) UP3 Bojonegoro sebagai berikut:

$$
\mathrm{Y}=0,368+0,053 \mathrm{X}_{1}+0,770 \mathrm{X}_{2}+\varepsilon
$$

Interpretasi hasil uji regresi linier berganda adalah sebagai berikut:

a) Konstanta $(\alpha)$ sebesar 0.368 memberi arti apabila variabel bebas Beban Kerja $\left(\mathrm{X}_{1}\right)$ dan Kepuasan Kerja (X2) adalah bernilai Konstan, maka besarnya variabel terikat yaitu Kinerja Karyawan (Y) adalah bernilai sebesar 0.368 satuan.

b) Dipersamaan regresi pada variabel Beban Kerja $\left(\mathrm{X}_{1}\right)$ memiliki koefisien sebesar 0,053 yang menunjukkan arah positif terhadap Kinerja Karyawan (Y). Apabila Beban Kerja $\left(\mathrm{X}_{1}\right)$ 
bertambah satu satuan, maka Kinerja Karyawan (Y) akan bertambah sebesar 0,053 satuan.

c) Dipersamaan regresi pada variabel Kepuasan Kerja (X2) memiliki koefisien sebesar 0,770 yang menunjukkan arah positif terhadap Kinerja Karyawan (Y). Apabila Kepuasan Kerja (X2) bertambah satu satuan, maka Kinerja Karyawan (Y) akan bertambah sebesar 0,770 satuan.

f. Koefisien Determinasi

Uji $\mathrm{R}^{2}$ digunakan untuk mengukur seberapa jauh kemampuan model dalam menjelaskan variabel dependen. Dalam penelitian ini koefisien determinasi menggunakan nilai $\mathbf{R}^{2}$.

Tabel 14. Koefisien Determinasi

\begin{tabular}{|c|c|c|c|c|}
\hline \multicolumn{5}{|c|}{ Model Summary ${ }^{\mathbf{b}}$} \\
\hline Model & $\mathrm{R}$ & R Square & $\begin{array}{l}\text { Adjusted } \\
\text { R Square }\end{array}$ & $\begin{array}{l}\text { Std. } \\
\text { Error }\end{array}$ \\
\hline 1 & $.806^{\mathrm{a}}$ & .650 & .643 & .38737 \\
\hline
\end{tabular}

a. Predictors: (Constant), X2, X1

b. Dependent Variable: Y

Sumber : Hasil Output SPSS 24

Dari hasil koefisien determinasi, diperoleh nilai $\mathrm{R}^{2}$ sebesar 0,650 atau $65.00 \%$. Hal ini menunjukkan bahwa Kinerja Karyawan di PT. PLN (Persero) UP3 Bojonegoro dapat dijelaskan sebesar $65.00 \%$ oleh variabel independen yaitu Beban Kerja $\left(\mathrm{X}_{1}\right)$ dan Kepuasan Kerja (X2). Sedangkan $35.00 \%$ variabel Kinerja Karyawan di usaha PT. PLN (Persero) UP3 Bojonegoro dijelaskan oleh variabelvariabel lain diluar variabel independen penelitian ini seperti lingkungan kerja, gaya kepemimpinan, stress kerja, komitmen, kompensasi, budaya organisasi dan lainnya.

\section{Uji Hipotesis}

Penelitian ini bertujuan untuk mengetahui pengaruh Beban Kerja $\left(\mathrm{X}_{1}\right)$ dan Kepuasan Kerja (X2) terhadap Kinerja Karyawan di PT. PLN (Persero) UP3 Bojonegoro (Y). Analisis dilakukan dengan menggunakan uji regresi linier berganda.

a. Uji Parsial (Uji t)

Uji $t$ digunakan untuk menguji koefisien regresi secara parsial dari variabel independennya, apakah masingmasing variabel Beban Kerja $\left(\mathrm{X}_{1}\right)$ dan Kepuasan Kerja (X2) berpengaruh terhadap variabel Kinerja Karyawan di PT.
PLN (Persero) UP3 Bojonegoro. Kriteria Kinerja Karyawan yaitu dengan melihat nilai signifikansi masing-masing variabel yang akan dibandingkan nilai derajat kesalahan sebesar 5\%.

Tabel 15. Hasil Uji t

\begin{tabular}{|c|c|c|c|c|}
\hline \multicolumn{5}{|c|}{ Coefficients $^{\mathrm{a}}$} \\
\hline \multirow{2}{*}{ Model } & $\begin{array}{r}\text { Uns } \\
\mathrm{C}\end{array}$ & $\begin{array}{l}\text { lardized } \\
\text { cients }\end{array}$ & \multirow[b]{2}{*}{$\mathrm{t}$} & \multirow{2}{*}{ Sig. } \\
\hline & B & $\begin{array}{l}\text { Std. } \\
\text { Error }\end{array}$ & & \\
\hline (Constant & .368 & .307 & 1.198 & .234 \\
\hline $\mathrm{X} 1$ & .062 & .099 & .632 & .529 \\
\hline $\mathrm{X} 2$ & .839 & .091 & 9.235 & .000 \\
\hline
\end{tabular}

a. Dependent Variable: Y

Sumber : Hasil Output SPSS 24

Berdasarkan Tabel 15 diperoleh $t_{\text {hitung }}$ Variabel $(\mathrm{X} 1=0,632)$ dan $\mathrm{t}_{\text {hitung }}$ Variabel $(\mathrm{X} 2=9,235), \mathrm{dF}$ $1=2$, dan $\mathrm{dF} 2=(97-(3)-1)=93$, sehingga diperoleh $\mathrm{t}_{\text {tabel }} 1.9858$ diperoleh melalui perhitungan $\mathrm{dk}=\mathrm{n}-1$.

a) Berdasarkan tabel dapat diperoleh nilai $t_{\text {hitung }}$ sebesar 0,632 dengan nilai Sig sebesar 0,529. Hal ini menunjukkan bahwa nilai $\mathrm{t}_{\text {hitung }}$ lebih kecil daripada nilai $t_{\text {tabel }} 1.9858$ dan nilai Sig lebih besar daripada 0,05. Dengan demikian Hipotesis ke-1 ditolak. Artinya variabel Beban Kerja mempunyai pengaruh positif dan tidak siginifikan terhadap Kinerja Karyawan di PT. PLN (Persero) UP3 Bojonegoro.

b) Berdasarkan tabel dapat diperoleh nilai $t_{\text {hitung }}$ sebesar 9,235 dengan nilai Sig sebesar 0,000. Hal ini menunjukkan bahwa nilai thitung lebih besar daripada nilai $t_{\text {tabel }} 1.9858$ dan nilai Sig lebih kecil daripada 0,05. Dengan demikian Hipotesis ke-2 diterima. Artinya variabel Kepuasan Kerja mempunyai pengaruh positif dan siginifikan terhadap Kinerja Karyawan di PT. PLN (Persero) UP3 Bojonegoro.

\section{Uji Simultan (Uji F)}

Uji $F$ dilakukan untuk mengetahui apakah variabel Beban Kerja $\left(\mathrm{X}_{1}\right)$ dan Kepuasan Kerja (X2) secara simultan (bersama-sama) berpengaruh terhadap variabel Kinerja Karyawan di PT. PLN (Persero) UP3 Bojonegoro. Hasil uji simultan dapat disajikan pada Tabel 4.14 sebagai berikut: 
Tabel 16 Hasil Uji F

\begin{tabular}{lrrcc}
\multicolumn{5}{c}{ ANOVA $^{\mathrm{a}}$} \\
Model & \multicolumn{5}{c}{ Mean } & & \\
\hline 1 Regression & 2 & Square & \multicolumn{1}{c}{ F } & Sig. \\
Residual & 94 & .107 & 87.345 & $.000^{\mathrm{b}}$ \\
Total & 96 & & & \\
\hline
\end{tabular}

a. Dependent Variable: Y

b. Predictors: (Constant), X2, X1

Sumber : Hasil Output SPSS 24

Berdasarkan Tabel 16. diperoleh $F_{\text {hitung }}$ 87.345, dF $1=(3-1)=2$, dan $\mathrm{dF} 2=(97-(3)$ $1)=93$, sehingga diperoleh $F_{\text {tabel }} 3.09$ diperoleh melalui perhitungan $\mathrm{dk}=\mathrm{n}-1$. Berdasarkan Tabel 18 diperoleh nilai $F_{\text {hitung }}$ sebesar 87.345 dengan nilai Sig sebesar 0,000. Hal ini menunjukkan bahwa nilai $F_{\text {hitung }}$ lebih besar dari $F_{\text {tabel }} 3.09$ dan nilai Sig lebih kecil dari 0,05. Dengan demikian $\mathrm{H} 3$ diterima. Artinya variabel Beban Kerja $\left(X_{1}\right)$ dan Kepuasan Kerja (X2) secara simultan (bersama-sama) berpengaruh terhadap variabel Kinerja Karyawan di PT. PLN (Persero) UP3 Bojonegoro. Dengan kata lain disimpulkan bahwa secara simultan variabel independen mempunyai pengaruh yang signifikan terhadap variabel dependen.

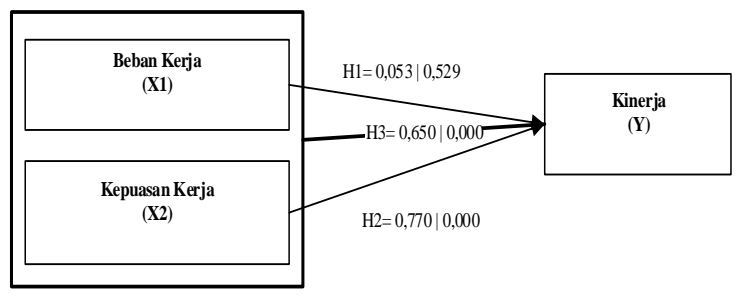

Gambar 3 Hasil Temuan Penelitian

Sumber : Hasil Olah Data Peneliti

Dari hasil analisis menggunakan Regresi Linier Berganda didapatkan data hasil temuan yang ditunjukkan pada Gambar 3 yang menunjukkan pengaruh dan hasil signifikansi tiap hipotesis. Untuk lebih jelasnya mengenai hasil temuan dapat dijelaskan sebagai berikut:

Hipotesis Pertama (H1) ditolak karena, nilai $t_{\text {hitung }}$ sebesar 0,632 dengan nilai Sig sebesar 0,529. Hal ini menunjukkan bahwa nilai $t_{\text {hitung }}$ lebih kecil daripada nilai $t_{\text {tabel }}$ 1.9858 dan nilai Sig lebih besar daripada 0,05. Hipotesis kedua (H2) diterima karena, diperoleh nilai $t_{\text {hitung }}$ sebesar 9,235 dengan nilai Sig sebesar 0,000. Hal ini menunjukkan bahwa nilai $t_{\text {hitung }}$ lebih besar daripada nilai $\mathrm{t}_{\text {tabel }} 1.9858$ dan nilai Sig lebih kecil daripada 0,05. Hipotesis ketiga (H3) diterima karena, diperoleh nilai $F_{\text {hitung }}$ sebesar 87.345 dengan nilai Sig sebesar 0,000. Hal ini menunjukkan bahwa nilai $F_{\text {hitung }}$ lebih besar dari $F_{\text {tabel }} 3.09$ dan nilai Sig lebih kecil dari 0,05.

\section{Pembahasan}

\section{Pengaruh Beban Kerja terhadap Kinerja Karyawan}

Hipotesis pertama dalam penelitian ini adalah diduga terdapat pengaruh positif dan signifikan secara langsung pada Beban Kerja $\left(\mathrm{X}_{1}\right)$ terhadap Kinerja karyawan PT. PLN (Persero) Bojonegoro (Y). Hasil analisis dengan regresi linier berganda menunjukkan nilai signifikansi sebesar 0,529 ( $p>0,05)$ yang berarti bahwa Beban Kerja $\left(\mathrm{X}_{1}\right)$ berpengaruh positif tidak signifikan terhadap Kinerja Karyawan di PT. PLN (Persero) UP3 Bojonegoro (Y).

Hasil penelitian ini tidak sejalan dengan teori Sunyoto (2012, p. 64) mengemukakan bahwa Beban kerja adalah beban pekerjaan yang terlalu banyak dan dapat menyebabkan ketegangan dalam diri seseorang sehingga menimbulkan stres hal ini di sebabkan oleh tingkat keahlihan yang dituntut terlalu tinggi, tingkat kecepatan kerja yang terlalu tinggi, volume pekerjaan yang terlalu banyak dan lain sebagainya.

Hasil penelitian ini tidak sejalandengan hasil penelitian yang dilakukan oleh (Rolos, Sambul, \& Rumawas, 2018), (Najiba, Rudi, \& Rafani, 2017), (Rindorindo, Murni, \& Trang, 2019), (Mahfudz, 2017) dan (Sagita \& Assa, 2019) yang membuktikan bahwa Beban Kerja $\left(\mathrm{X}_{1}\right)$ berpengaruh terhadap Kinerja Karyawan (Y). Yang meyatakan semakin tinggi beban kerja yang ada, maka akan semakin rendah kinerja karyawan begitupula jika semakin rendah beban kerja karyawan maka akan meningkatkan kinerja karyawan yang ada.

Tidak adanya pengaruh yang nyata antara Beban Kerja terhadap Kinerja Karyawan menunjukan bahwa, tingginya target yang menimbulkan Beban Kerja yang ada di PT. PLN (Persero) UP3 Bojonegoro sehingga membuat para karyawan tidak bisa bekerja dengan bahagia, namun apabila dari pihak atasan memberikan apresiasi dan dukungan seperti gaji yang sesuai dengan target beban karyawan, yang mana dikarenakan tingginya target kerja diimbangi dengan tambahan gaji yang diharapkan dengan semakin tinggi 
apreasi dalam bentuk gaji ini dapat memberikan kinerja yang lebih baik lagi. Selain bentuk apreasiasi dalam bentuk gaji, juga dapat dilakukan adanya seminar/gatering yang nantinya diharapkan dapat menimbulkan motivasi bekerja yang lebih baik dari target bulanan yang tinggi dan mengurangi kebosanan sehingga karyawan dapat berinovasi dalam menyelesaikan pekerjaannya. Saran pada PT. PLN (Persero) UP3 Bojonegoro supaya dapat mengurangi Beban Kerja agar supaya Kinerja Karyawan dapat meningkat kedepannya.

Hasil berpengaruh positif namun tidak signifikan ini juga dipengaruhi oleh faktor jenis kelamin responden yang mayoritas lakilaki sebanyak 83 orang $(85,6 \%)$ dan berada pada divisi Operasi sebanyak 46 orang $(47,4 \%)$, dimana beban kerja terbanyak memang divisi pelayanan utamanya pada divisi operasi jaringan yang bekerja diluar ruangan dengan jam kerja yang kurang proporsional serta mempunya target yang tinggi. Dimana hasil ini mendukung penelitian Wilda, Sunaryo, \& Wahono (2020, p. 58) yang menyatakan bahwa antara karyawan yang bergender laki-laki dan perempuan memiliki perilaku kerja yang sama dalam menyelesaikan tugasnya, namun gender lakilaki dan perempuan memiliki kemampuan yang berbeda dalam menyelesaikan pekerjaan yang dianggap berat.

\section{Pengaruh Kepuasan Kerja terhadap Kinerja Karyawan}

Hipotesis kedua dalam penelitian ini adalah untuk mengetahui pengaruh Kepuasan Kerja (X2) terhadap Kinerja Karyawan di PT. PLN (Persero) UP3 Bojonegoro. Hasil analisis dengan regresi linier berganda menunjukkan nilai signifikansi sebesar $0,000 \quad(p<0,05)$ yang berarti bahwa Kepuasan Kerja (X2) berpengaruh secara positif terhadap Kinerja Karyawan di PT. PLN (Persero) UP3 Bojonegoro (Y).

Hasil penelitian ini sejalan dengan teori yang disampaikan terkait pengertian kepuasan kerja merupakan evaluasi yang menggambarkan seseorang atas perasaan sikapnya, senang atau tidak senang, puas, atau tidak puas dalam bekerja (Rivai, 2014, p. 97). Selain itu hasil penelitian ini sejalan dengan hasil penelitian yang dilakukan yaitu (Najiba, Rudi, \& Rafani, 2017), (Rindorindo, Murni, \& Trang, 2019), (Mahfudz, 2017), (Sagita \& Assa, 2019) dan (Hafid, 2019) yang membuktikan bahwa variabel Kepuasan Kerja $\left(\mathrm{X}_{2}\right)$ berpengaruh terhadap Kinerja Karyawan (Y). Ini berarti karyawan yang ada pada perusahaan tersebut memiliki rasa kepuasan setelah melakukan pekerjaan sehingga karyawan semakin giat meningkatkan kinerjanya.

Adanya pengaruh yang nyata antara Kepuasan Kerja terhadap kinerja karyawan menunjukan Kepuasan Kerja merupakan salah satu peran tiap individu dalam menciptakan kinerja yang lebih baik dengan menyenangi dan mencintai pekerjaan, adanya disiplin kerja hingga mendapatkan prestasi kerja secara relatif merasa puas serta mendapatkan kesempatan untuk tumbuh dan berkembang. Saran pada PT. PLN (Persero) UP3 Bojonegoro supaya tetap mempertahankan Kepuasan Kerja agar supaya Kinerja Karyawan tetap bertahan baik kedepannya.

Hasil berpengaruh positif dan signifikan ini juga dipengaruhi oleh faktor usia responden yang didominasi pada usia $\leq 25$ Tahun yaitu sebanyak 48 orang $(49,5 \%)$, dimana mayoritas karyawan pada PT. PLN (Persero) UP3 Bojonegoro berada pada usia muda dan produktif. Dimana hasil ini mendukung penelitian Widakdo, Holik, \& Iska (2021) yang menjelaskan apabila usia yang semakin tua bukan berarti seseorang memiliki ilmu atau pengetahuan yang lebih baik dibandingkan dengan anggota yang usianya lebih muda karena usia yang lebih muda cenderung memiliki daya tangkap dan ingatan yang lebih baik terhadap informasi yang baru dibandingkan dengan usia yang lebih tua. Usia juga mempengaruhi tingkat kestabilan emosi seseorang dalam menghadapi setiap permasalahan. Usia yang lebih tua cenderung memiliki tingkat kestabilan emosi yang lebih baik dibandingkan dengan usia yang muda. Umur berkaitan erat dengan tingkat kedewasaan atau maturitas pegawai. Kedewasaan adalah tingkat kemampuan teknis dalam melakukan tugas maupun kedewasaan psikologis, semakin bertambah lanjut usia seseorang semakin meningkat pula kedewasaan seseorang, demikian juga psikologisnya akan menunjukkan kematangan jiwa. Robbins \& Judge dalam (Widakdo, Holik, \& Iska, 2021, p. 57) mengungkapkan bahwa jika penelitian memisahkan antara profesional dan non profesional, maka akan didapatkan bahwa tingkat kinerja cenderung meningkat pada profesional dengan bertambahnya usia, 
sedangkan pada nonprofesional kinerja menurun seiring dengan pertambahan usia.

\section{Pengaruh Beban Kerja $\left(X_{1}\right)$ dan Kepuasan Kerja (X2) terhadap variabel Kinerja Karyawan}

Hipotesis ketiga menguji pengaruh Beban Kerja $\left(\mathrm{X}_{1}\right)$ dan Kepuasan Kerja (X2) terhadap variabel Kinerja Karyawan secara simultan. Hipotesis tersebut diuji melalui uji F yang menunjukkan nilai signifikansi sebesar $0,000(\mathrm{p}<0,05)$. Sehingga dapat disimpulkan bahwa Beban Kerja $\left(\mathrm{X}_{1}\right)$ dan Kepuasan Kerja (X2) secara bersama-sama berpengaruh terhadap Kinerja Karyawan. Nilai koefisien determinasi yang diperoleh sebesar $65.0 \%$ yang menunjukkan bahwa Kinerja Karyawan di PT. PLN (Persero) UP3 Bojonegoro dapat dijelaskan sebesar $65.0 \%$ oleh variabel independen yaitu Beban Kerja $\left(\mathrm{X}_{1}\right)$ dan Kepuasan Kerja (X2). Beban Kerja dan Kepuasan Kerja berkontribusi terhadap kinerja karyawan. Hal ini berarti bahwa Beban Kerja yang sesuai kapasitas jumlah karyawan dan tingkat keahlian karyawan serta Kepuasan Kerja yang baik mampu meningkatkan kinerja karyawan.

Pernyataan ini didukung oleh beberapa peneliti terdahulu yaitu (Najiba, Rudi, \& Rafani, 2017), (Rindorindo, Murni, \& Trang, 2019), (Sagita \& Assa, 2019) dan (Hafid, 2019) yang membuktikan bahwa variabel Beban Kerja $\left(\mathrm{X}_{1}\right)$ dan Kepuasan Kerja $\left(\mathrm{X}_{2}\right)$ berpengaruh terhadap Kinerja Karyawan (Y). Hal ini membuktikan bahwa, jika adanya beban kerja dan kepuasan kerja yang semakin baik maka akan meningkatkan kinerja karyawan. Diperoleh hasil kesimpulan secara simultan/bersama-sama Beban Kerja $\left(\mathrm{X}_{1}\right)$ dan Kepuasan Kerja (X2) berpengaruh signifikan terhadap Kinerja Karyawan.

\section{Simpulan}

Simpulan yang diperoleh berdasarkan penelitian ini adalah sebagai berikut:

1. Beban Kerja berpengaruh positif tidak signifikan terhadap Kinerja Karyawan di PT. PLN (Persero) UP3 Bojonegoro. Hasil berpengaruh positif namun tidak signifikan ini juga dipengaruhi oleh faktor jenis kelamin responden yang mayoritas laki-laki sebanyak 87 orang $(85,6 \%)$ dan berada pada divisi Operasi sebanyak 46 orang $(47,4 \%)$, dimana beban kerja terbanyak memang divisi pelayanan utamanya pada divisi operasi jaringan yang bekerja diluar ruangan dengan jam kerja yang kurang proporsional serta mempunya target yang tinggi. Dimana hasil ini mendukung penelitian Wilda, Sunaryo, \& Wahono (2020, p. 58) yang menyatakan bahwa antara karyawan yang bergender lakilaki dan perempuan memiliki perilaku kerja yang sama dalam menyelesaikan tugasnya, namun gender laki-laki dan perempuan memiliki kemampuan yang berbeda dalam menyelesaikan pekerjaan yang dianggap berat.

2. Kepuasan Kerja berpengaruh positif dan signifikan terhadap Kinerja Karyawan di PT. PLN (Persero) UP3 Bojonegoro. Hasil berpengaruh positif dan signifikan ini juga dipengaruhi oleh faktor usia responden yang didominasi pada usia $\leq 25$ Tahun yaitu sebanyak 48 orang $(49,5 \%)$, dimana mayoritas karyawan pada PT. PLN (Persero) UP3 Bojonegoro berada pada usia muda dan produktif. Dimana hasil ini mendukung penelitian Widakdo, Holik, \& Iska (2021) yang menjelaskan apabila usia yang semakin tua bukan berarti seseorang memiliki ilmu atau pengetahuan yang lebih baik dibandingkan dengan anggota yang usianya lebih muda karena usia yang lebih muda cenderung memiliki daya tangkap dan ingatan yang lebih baik terhadap informasi yang baru dibandingkan dengan usia yang lebih tua.

3. Beban Kerja dan Kepuasan Kerja berpengaruh secara simultan terhadap Kinerja Karyawan di PT. PLN (Persero) UP3 Bojonegoro. Hal ini berarti bahwa Beban Kerja yang sesuai kapasitas jumlah karyawan dan tingkat keahlian karyawan serta Kepuasan Kerja yang Saran

baik mampu meningkatkan kinerja karyawan.

Penulis memberikan saran sebagai berikut:

1. Bagi manajemen PT. PLN (Persero) UP3 Bojonegoro, variable Beban Kerja memiliki pengaruh positif dan tidak signifikan sehingga dapat diperhatikan lagi dengan pengaruh yang sangat kecil. Diharapkan pada PT. PLN (Persero) UP3 Bojonegoro mengurangi beban kerja yang melebihi kapasitas sehingga membuat para karyawan bekerja dengan bahagia, dan apabila dari pihak atasan memberikan apresiasi dan dukungan seperti seminar/gatering yang nantinya diharapkan dapat menimbulkan motivasi bekerja yang lebih baik sehingga karyawan dapat berinovasi dalam menyelesaikan pekerjaannya.

2. Bagi manajemen PT. PLN (Persero) UP3 Bojonegoro, variable Kepuasan Kerja memiliki 
pengaruh paling besar sehingga dapat menjadi bahan evaluasi bagi pihak PT. PLN (Persero) UP3 Bojonegoro dalam meningkatkan Kepuasan Kerja dengan cara terus meningkatkan dan mempertahankan Kepuasan Kerja yang dirasakan karyawan seperti "Karyawan memahami cara melaksanakan pekerjaannya, sehingga bisa mengerjakannya dengan baik", "Karyawan merasa bahwa pekerjaan dibidang kelistrikan adalah pekerjaan yang dicintai", "Karyawan merasakan ketenangan batin saat bekerja" dan faktor lainnya, sehingga dapat diperoleh variabelvariabel lain yang berguna bagi pengembangan PT. PLN (Persero) UP3 Bojonegoro.

3. Bagi peneliti yang akan datang, penelitian ini hanya memfokuskan pada kajian mengenai Beban Kerja dan Kepuasan Kerja terhadap Kinerja Karyawan bagian jaringan di PT. PLN (Persero) UP3 Bojonegoro, diharapakan peneliti dapat menambahkan variabel-variabel baru sehingga dapat memberikan nilai indeks yang lebih tinggi serta dapat menghasilkan gambaran yang lebih luas mengenai masalah yang sedang diteliti.

\section{DAFTAR PUSTAKA}

Akdon, \& Riduwan. (2013). Rumus dan Data Dalam Analisis Statiska. Jakarta: Alfabeta.

Fatihudin, D. (2015). Metodologi Penelitian Untuk Ilmu Ekonomi, Manajemen dan Akuntansi : Dari teori ke praktek. Sidoarjo: Zifatama Publishing.

Ghozali, I. (2013). Aplikasi Analisis Multivariat dengan Program IBM SPSS. Edisi 7. . Semarang: Penerbit Universitas Diponegoro.

Gibson et al. (2012). Organisasi dan Manajemen. Jakarta: Erlangga.

Hafid, I. (2019). Pengaruh Beban Kerja, Stress Kerja, Kepuasan Kerja Terhadap Kinerja Karyawan Pada PT. PLN (Persero) UP2B Sistem Makassar . Tesis, 1-192.

Hasibuan, M. S. (2016). Manajemen Sumber Daya Manusia. Jakarta: PT. Bumi Aksara.

LayananPLN. (2016, 10 31). Layanan Listrik Makin Mudah dengan PLN Mobile. Retrieved 07 04, 2021, from Info Layanan PLN: $\quad$ https://layanan.pln.co.id/infolayanan-pln/layanan-listrik-makin-mudahdengan-pln-mobile

Mahfudz, M. (2017, Juni ). Pengaruh Kepuasan Kerja Dan Beban Kerja Terhadap Kinerja Karyawan Dan Stres Kerja Sebagai Variabel Mediasi Pada Karyawan Divisi
Sales Consumer PT Bank Negara Indonesia (Persero)Tbk. Jurnal Eksekutif, Volume 14 No. 1, 51-75.

Malhotra, N. (2010). Riset Pemasaran Pendekatan Terapan (Edisi Keempat, Jilid 2 ed.). Jakarta: PT Indeks.

Munandar. (2012). Psikologi Industry dan Organisasi. Jakarta: Universitas Indonesia. Najiba, B. U., Rudi, A., \& Rafani, Y. (2017, November). Analisis Pengaruh Kepuasan Kerja Dan Beban Kerja Terhadap Kinerja Karyawan (Studi Kasus Pada Dealer Honda PT Nusantara Surya Sakti Cabang Pangkalpinang). Jurnal Ilmiah Progresif Manajemen Bisnis (JIPMB), Volume 18, Nomor 2, 40-47.

Pio, J. R. (2015). Kepemimpinan Spiritual : Dimensi-Dimensi Sumber Daya Manusia. Yogyakarta : Kepel Pers.

Rindorindo, R. P., Murni, S., \& Trang, I. (2019, Oktober ). Pengaruh Beban Kerja, Stres Kerja Dan Kepuasan Kerja Terhadap Kinerja Karyawan Hotel Gran Puri. Jurnal EMBA, Vol.7 No.4 , 5953-5962.

Rivai, V. (2014). Manajemen Sumber Daya Manusia untuk Perusahaan (6 ed.). Depok: PT. Raja Grafindo Persada.

Robbin, S. P., \& Timothy, A. (2015). Perilaku Organisasi (16 ed.). Jakarta: Selemba Empat.

Rolos, J. K., Sambul, S. A., \& Rumawas, W. (2018). Pengaruh Beban Kerja Terhadap Kinerja Karyawan Pada PT. Asuransi Jiwasraya Cabang Manado Kota. Jurnal Administrasi Bisnis, Vol. 6 No. 4, 19-27.

Sagita, D., \& Assa, A. F. (2019, Juli - Desember). Pengaruh Kepuasan Kerja Dan Beban Kerja Terhadap Kinerja Karyawan PT. Airmas Perkasa. Jurnal Ilmiah Manajemen Bisnis, Vol. 19, No. 2, 1-14.

Sugiyono. (2015). Metode Penelitian Kombinasi (Mix Methods). Bandung: Alfabeta.

Sunyoto. (2012). Manajemen sumber daya manusia. Jakarta: PT. BUKU SERU.

Sutrisno, E. (2015). Budaya Organisasi. Jakarta: Prenada Media.

Wahjono et al. (2020). Perilaku Organisasi Di Era Revolusi Industri 4.0. Depok: PT. Raja Grafindo Persada.

Wibowo. (2016). Manajemen Kinerja. Jakarta: Rajawali Press.

Widakdo, D. S., Holik, A., \& Iska, L. N. (2021). Efek Usia dan Tingkat Pendidikan terhadap Kinerja Tenaga Bantu Penyuluh Pertanian. Jurnal Penyuluhan, Vol. 17 (01), 52-59. 


\section{Tufaila dan Santoso}

Wilda, A. Y., Sunaryo, H., \& Wahono, B. (2020). Analisis Pengaruh Gender, Beban Kerja, dan Motivasi Kerja terhadap Kinerja. $e-$ Jurnal Riset Manajemen PRODI MANAJEMEN Fakultas Ekonomi dan Bisnis Unisma, 48-61. 